\title{
Intercomponent and interfacial electron transfer processes in polynuclear metal complexes anchored on transparent $\mathrm{TiO}_{2}$ films
}

\author{
C A BIGNOZZI**, R ARGAZZI", M T INDELLI", F SCANDOLA ${ }^{*}$, \\ J R SCHOONOVER ${ }^{\mathrm{b}}$ and G J MEYER ${ }^{\mathrm{c}}$ \\ "Dipartimento di Chimica, Università di Ferrara, via L Borsari 46-44100 Ferrara, \\ Italy

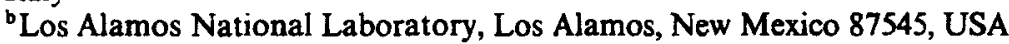 \\ 'Department of Chemistry, Johns Hopkins University, Baltimore, \\ Maryland 21218, USA
}

\begin{abstract}
A series of polynuclear complexes based on $\mathrm{Ru}^{\mathrm{II}}, \mathrm{Os}^{\mathrm{II}}, \mathrm{Re}^{\mathrm{i}}$ and $\mathrm{Rh}^{\mathrm{III}}$ polypyridine moieties have been prepared in the context of intramolecular energy and electron transfer studies and of interfacial electron transfer with nanocrystalline $\mathrm{TiO}_{2}$. The polynuclear complexes allow for the occurrence of vectorial intramolecular energy and electron transfer and have been proven to be efficient sensitizers of the wide band-gap semiconductor. The performance of photoregenerative cells based on these systems and the dynamics of the excited state intramolecular processes and of the interfacial electron transfer processes are discussed.
\end{abstract}

Keywords. Polynuclear metal complexes; interfacial electron transfer studies; sensitizers; nanocrystalline $\mathrm{TiO}_{2}$.

\section{Introduction}

In polynuclear complexes based on transition metal ions, photoinduced electron and energy transfer processes between molecular components can take place. The study of such processes on molecular systems in homogeneous solutions has undergone a considerable expansion in the past years ${ }^{1-3}$. Recently there has been considerable interest in light-induced electron transfer reactions between light absorbing chromophores and nanometer-sized semiconductor clusters, largely motivated by the impressive solar energy conversion efficiencies reported by Grätzel and co-workers for molecular sensitizers adsorbed on porous colloidal $\mathrm{TiO}_{2}$ films ${ }^{4}$.

Sensitization of semiconductors implies an extension of their photosensitivity in a wavelength range beyond the bandgap energy. In the sensitization process, figure 1, an electronically excited dye molecule, which is adsorbed on the surface of the semiconductor, injects an electron into the conduction band allowing photoelectrochemical processes to occur ${ }^{4}$.

The possibility of solar energy conversion through this process encouraged large research activities in the past ${ }^{5}$, but only in recent years substantial advances have been made with the introduction of high surface area nanocrystalline $\mathrm{TiO}_{2}$ electrodes ${ }^{4}$ and with an appropriate design of the molecular sensitizer ${ }^{6-7}$.

In this article we present some examples from a research program directed to the synthesis, spectroscopic and photoelectrochemical characterization of novel sensitizers, namely, cyano-bridged polynuclear metal complexes which allow for the

*For correspondence 


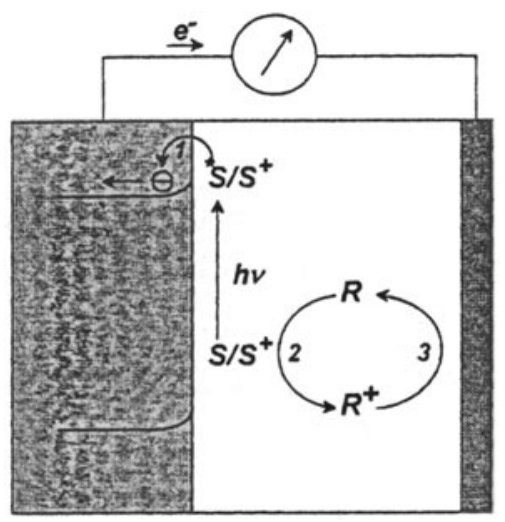

Figure 1. Schematic representation of the elementary steps involved in a regenerative photoelectrochemical cell for light conversion based on dye sensitization of semiconductors.

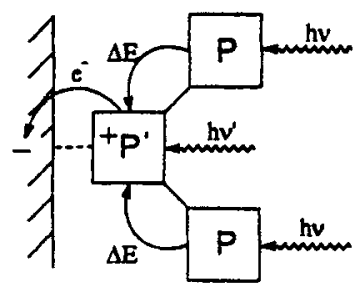

a

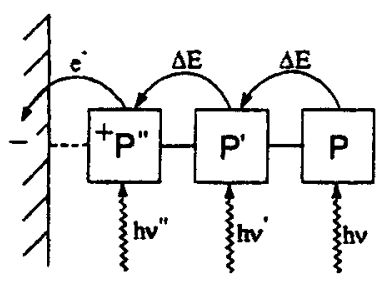

b

Figure 2 Sequence of intramolecular energy transfer and interfacial electron transfer processes involving branched (a), and one dimensional (b) triad systems adsorbed on a semiconductor.

occurrence of efficient intramolecular energy transfer and of supramolecular sensitizers based on inorganic building blocks which allow for the occurrence of vectorial intramolecular electron transfer process. Some examples of applications of recently developed time-resolved vibrational spectroscopies will also be discussed to show the potential of these techniques in monitoring intercomponent energy transfer processes in complex molecular systems.

\section{Antenna effect.}

As far as the antenna effect is concerned, different schemes can be conceived in order to increase the efficiency of light harvesting on a semiconductor surface. Two simple 
prototypes, following the "branched" or "one-dimensional" design are shown schematically in figure 2. Extension of the two types of design to larger antenna systems is intuitive. The obvious requisites for the supramolecular species to be used in such systems are (i) an efficient antenna effect, leading the absorbed energy towards a molecular component; (ii) the capability for the molecular component bound to the semiconductor surface, once excited, to inject electrons into the conduction band. An apriori evaluation of the two types of design is difficult, as both have virtues and limitations.

First, there are some energy-related problems pertaining to the supramolecular system as such. If a finite energy demand is considered for each energy transfer step, a branched design, where extensive use of parallel processes is made, is clearly energy-saving relative to the one-dimensional design, where all the processes are in series. If, however, fast isoenergetic energy hopping between components can take place, followed by trapping at the lowest-energy component sitting on the surface, then the difference between the two types of design becomes much less critical. In the first hypothesis, the dimensions of the antenna system cannot be increasd without introducing energy losses. In the second instance, on the other hand, quite large antenna systems could be envisioned.

Then, there are aspects which are specific to the supermolecule-semiconductor system. For a supramolecular system considered as an independent photochemical molecular device an obvious expectation is that "the larger the antenna system, the larger the light harvesting efficiency". The same is not necessarily true for light-toenergy conversion on a semiconductor. A highly branched supramolecular system projects (i.e. occupies) a much larger area than a simple molecular sensitizer onto the semiconductor surface. At saturation surface coverage, this would strongly reduce the gain represented by the antenna effect. From this point of view, the one-dimensional design would look superior to the branched one, as one could think of increasing indefinitely the nuclearity of the supramolecular system without substantially increasing the projected (occupied) area.

In a first attempt to demonstrate the feasibility of such an approach, the [NC$\left.\mathrm{Ru}(\mathrm{bpy})_{2}-\mathrm{CN}-\mathrm{Ru}\left(4,4^{\prime}-\mathrm{dcb}\right)_{2}-\mathrm{NC}-\mathrm{Ru}(\mathrm{bpy})_{2}-\mathrm{CN}\right]^{2}$ complex was developed $\left(4,4^{\prime} \mathrm{dcb}\right.$ is $4,4^{\prime}$ dicarboxy-2,2'-bipyridine) ${ }^{6 \mathrm{a}}$. The carboxylic functions present on the central unit provide the linkage with the semiconductor. Efficient energy funnelling from the peripheral chromophores to this unit was demonstrated by conventional photophysical experiments ${ }^{6 \mathrm{a}}$ and by time-resolved resonance $\operatorname{Raman}^{8}$. The transient Raman spectrum of the trinuclear complex, obtained using $354.7 \mathrm{~nm}$ laser pulses to both excite the sample and probe the excited state, lacks the typical intense Raman bands for $\left(\mathrm{bpy}^{-}\right)$. Bands due to ground-state bpy vibrations are present at 1561 and $1605 \mathrm{~cm}^{-1}$. Clear evidence that energy transfer has occurred to the inner $-R u\left(4,4^{\prime}-\mathrm{dcb}\right)_{2}$-unit is shown by the presence of bands at $1113,1289,1446,1488$ and $1552 \mathrm{~cm}^{-1}$ for $\left(4,4^{\prime}-\mathrm{dcb}^{-}\right)$which also appear in the transient spectrum of $\mathrm{Ru}\left(4,4^{\prime}-\mathrm{dcb}\right)_{2}(\mathrm{CN})_{2}^{4-8}$.

In experiments carried out using $\mathrm{TiO}_{2}$-coated electrodes in aqueous solution at $p \mathrm{H}$ 3.5 , photocurrents were obtained upon irradiation with visible light. The photocurrent spectrum was observed to reproduce the absorption spectrum of the complex, indicating that the efficiency of conversion of absorbed light is constant throughout the spectrum, regardless of whether the incident light is absorbed by the central unit or by the terminal ones ${ }^{6 a}$. Subsequent experiments on this complex adsorbed on polycrystalline $\mathrm{TiO}_{2}$ gave an overall conversion efficiency of $7 \%$ with turnover numbers of at least 
five millions without decomposition ${ }^{4,9}$. Considerable efficiencies were also observed with related compounds containing $\mathrm{Ru}\left(4,4^{\prime}-\mathrm{X}_{2} \text { bpy }\right)_{2}(\mathrm{CN})_{2}\left(\mathrm{X}=\mathrm{COOH}, \mathrm{CH}_{3}, \mathrm{C}_{6} \mathrm{H}_{5}\right)$ and phenanthroline-containing analogues, as lateral units ${ }^{6 \mathrm{~b}}$.

Polynuclear species containing the $\mathrm{Ru}\left(5,5^{\prime}-\mathrm{dcbH}_{2}\right)_{2}(\mathrm{CN})_{2}$ sensitizer $\left(5,5^{\prime}-\mathrm{dcbH}_{2}=5\right.$, $5^{\prime}$-dicarboxy-2,2'bipyridine) have recently been developed ${ }^{8 b}$. The presence of carboxylic function in 5,5' position cause a decrease in energy of the MLCT transitions with a consequent red shift of the visible absorption spectrum. Analogously to that found for the brown $\left[\mathrm{NC}-\mathrm{Ru}(\mathrm{bpy})_{2}-\mathrm{CN}-\mathrm{Ru}\left(4,4^{\prime}-\mathrm{dcb}\right)_{2}-\mathrm{NC}-\mathrm{Ru}(\mathrm{bpy})_{2}-\mathrm{CN}\right]^{2}$ sensitizer, a close matching between absorption and photocurrent distribution at the different wavelengths was observed for the green [NC-Ru(bpy) ${ }_{2}-\mathrm{CN}-\mathrm{Ru}\left(5,5^{\prime}-\mathrm{dcb}\right)_{2}-\mathrm{NC}-\mathrm{Ru}$ (bpy) $\left.{ }_{2}-\mathrm{CN}\right]^{2-}$ complex, supporting the presence of efficient antenna effects ${ }^{8 b}$.

Another class of polynuclear complexes recently investigated can be described by the general formula,

$$
\left[(\mathrm{NC}) \mathrm{M}^{\mathrm{II}}(\mathrm{LL})_{2}-\mathrm{CN}-\left[\mathrm{Ru}^{\mathrm{II}}(\mathrm{bpy})_{2}-\mathrm{CN}-\right]_{\mathrm{n}} \mathrm{Ru}^{\mathrm{II}}(\mathrm{bpy})_{2}(\mathrm{CN})\right]^{(\mathrm{n}+1)+}
$$

where the metal polypyridine moiety, $\mathrm{M}(\mathrm{LL})_{2}(\mathrm{CN})_{2}$, has ${ }^{3} \mathrm{MLCT}$ states at lower energy with respect to those of the intermediate or terminal $\mathrm{Ru}(\mathrm{bpy})_{2}(\mathrm{CN})$ moieties. This arrangement offers the possibility of exploring vectorial energy transfer efficiency driven towards the energy sink represented by $\mathrm{M}(\mathrm{LL})_{2}(\mathrm{CN})_{2}$.

Despite the unfavourable energetic asymmetry imposed by the bridging cyanides, energy transfer to $M(L L)_{2}(C N)_{2}$ is observed when this unit is a complex of the type, cis-Os(bpy $)_{2}(\mathrm{CN})_{2}$, cis- $\left[\mathrm{Os}{ }^{\mathrm{II}}\left(4,4^{\prime} \mathrm{dcb}\right)_{2}(\mathrm{CN})_{2}\right]^{4-}$, cis- $\left[\mathrm{Ru}\left(5,5^{\prime} \mathrm{dcb}\right)_{2}(\mathrm{CN})_{2}\right]^{4-}$ or $\left[\mathrm{Ru}\left(4,4^{\prime}-\mathrm{dcb}\right)(\mathrm{CN})_{4}\right]^{4-}$. General evidence for efficient energy transfer, in this direction, along such chains comes from trends in the photophysical parameters. As an example, the emission spectra of the trinuclear complex,

$$
\left[(\mathrm{NC}) \mathrm{OS}^{\prime \prime}\left(4,4^{\prime}-\mathrm{dcb}\right)_{2}-\mathrm{CN}-\left[\mathrm{Ru}^{\mathrm{II}}(\mathrm{bpy})_{2}-\mathrm{CN}-\right] \mathrm{Ru}^{\mathrm{II}}(\mathrm{bpy})_{2}(\mathrm{CN})\right]^{2-}
$$

and of the mononuclear component $\left[\mathrm{Os}^{\mathrm{II}}\left(4,4^{\prime}-\mathrm{dcb}\right)_{2}(\mathrm{CN})_{2}\right]^{4-}$ are shown in figure 3 .

The emission of the trinuclear species can clearly be assigned to an Os-based emission. This emission is slightly blue shifted with respect to that of the free Os component due to the electron withdrawing effect of the adjacent Ru center ${ }^{3}$. The coincidence between excitation and absorption spectra, together with the lack of evidence for higher energy Ru-based emissions, strongly supports efficient energy transfer to the Os unit of the trinuclear complex.

In the case of the trinuclear complex $\left[\left(4,4^{\prime}-\mathrm{dcb}\right) \mathrm{Ru}(\mathrm{CN})_{3}-\mathrm{CN}-\mathrm{Ru}(\mathrm{bpy})_{2}-\mathrm{CN}-\mathrm{Ru}\right.$ (bpy) $\left.{ }_{2}-\mathrm{CN}\right]^{2-}$, taken as an additional example, photoluminescence is observed to be strongly solvent dependent due to well known specific solvent interactions operating at the terminal cyanides ${ }^{10}$. These interactions, which involve the solvent molecule and the lone pair of electrons centered on the nitrogen atoms of the $\mathrm{CN}$ ligands, are observed to be almost additive, being linearly dependent on the number of terminal $\mathrm{CN}$ ligands ${ }^{10}$. The above trinuclear complex is therefore peculiar in that solvent changes may control the direction of the energy transfer process. The comparison of the emission spectrum of this species with those of the model binuclear [(NC)Ru(bpy) ${ }_{2}$ $\left.\mathrm{CN}-\mathrm{Ru}(\mathrm{bpy})_{2}(\mathrm{CN})\right]^{+}$and mononuclear $\left[\left(4,4^{\prime}-\mathrm{dcb}\right) \mathrm{Ru}(\mathrm{CN})_{4}\right]^{2-}$ complexes show, in fact that in solvents with high acceptor number ${ }^{11}$, such as water or methanol, the emission energies follow the order, mononuclear $>$ binuclear $>$ trinuclear, while in less accepting solvents as dimethylformammide or acetonitrile, the emission energies are in the order binuclear $>$ trinuclear $>$ mononuclear. This result is consistent with energy 


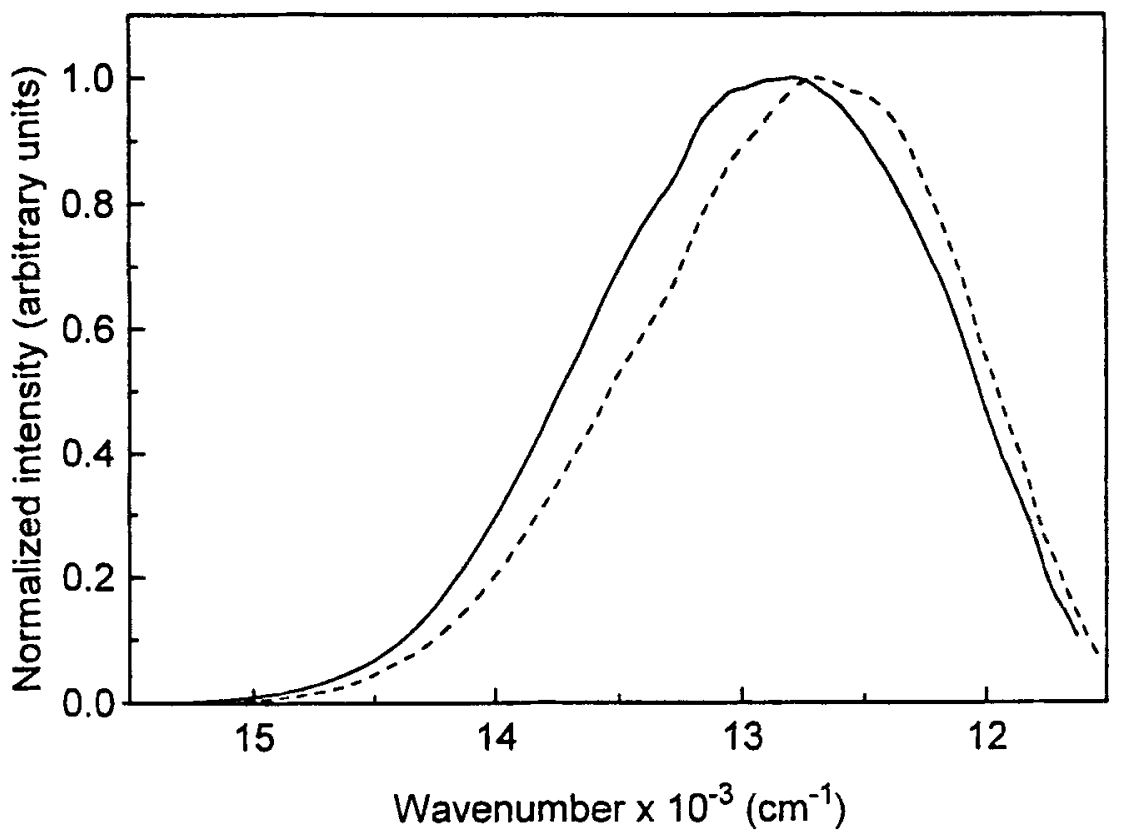

Figure 3. Emission spectra of $\left[\left(\mathrm{NClO} s^{\mathrm{II}}\left(4,4^{\prime}-\mathrm{dcb}\right)_{2}-\mathrm{CN}-\left[\mathrm{Ru}^{\mathrm{II}}(\mathrm{bpy})_{2}-\mathrm{CN}-\right] \mathrm{Ru} \mathrm{u}^{\mathrm{II}}(\mathrm{bpy})_{2}\right.\right.$ $(\mathrm{CN})]^{2-}$ (continuous line) and $\left[\mathrm{Os}^{\mathrm{II}}\left(4,4^{\prime}-\mathrm{dcb}\right)_{2}(\mathrm{CN})_{2}\right]^{4-}$ (dashed line) in methanol.

transfer from MLCT excited states localized on the $\left[\left(4,4^{\prime}-\mathrm{dcb}\right) \mathrm{Ru}(\mathrm{CN})_{3}\right]^{-}$unit to MLCT states localized on the terminal-CN-Ru(bpy $)_{2}(\mathrm{CN})$ unit in highly polar solvents and with the inversion of the direction of this process in solvents of low polarity. In high polar solvents, efficient energy transfer from $\left(4,4^{\prime}-\mathrm{dcb}\right) \mathrm{Ru}(\mathrm{CN})_{3}$ - to the $\mathrm{Ru}(\mathrm{bpy})_{2}$ unit was clearly demonstrated by time resolved resonance $\operatorname{Raman}\left(\mathrm{TR}^{3}\right)$ experiments. The transient Raman spectra of $\left[\left(4,4^{\prime}-\mathrm{dcb}\right) \mathrm{Ru}(\mathrm{CN})_{3}-\mathrm{CN}-\mathrm{Ru}(\mathrm{bpy})_{2}-\mathrm{CN}-\mathrm{Ru}(\mathrm{bpy})_{2}-\mathrm{CN}\right]^{2-}$ and of the model mononuclear complexes $\left[\left(4,4^{\prime}-\mathrm{dcb}\right) \mathrm{Ru}(\mathrm{CN})_{4}\right]^{4-}$ and $\left[(\mathrm{bpy}) \mathrm{Ru}(\mathrm{CN})_{4}\right]^{4-}$ are shown in figure 4.

Relevant band assignments are reported in Table 1 . These spectra were obtained under identical conditions using $532 \mathrm{~nm}$ excitation pulses and probe pulses of $355 \mathrm{~nm}$. The TR ${ }^{3}$ spectrum of the trinuclear complex lacks of bands due to $\left(\mathrm{dcb}^{-}\right)$, while bands due to bpy ${ }^{-}$ are evident at 1210,1278,1416,1545 $\mathrm{cm}^{-1}$ (figure 4a). Bands due to ground state dcb vibrations are observed at $1437,1487,1610 \mathrm{~cm}^{-1}$. These results are consistent with localization of the lowest MLCT state on a Ru(bpy $)_{2}$ moiety of the trinuclear complex.

In comparative photoelectrochemical experiments in acetonitrile, figure 5, a higher photocurrent response was observed for $\left[\left(4,4^{\prime}-\mathrm{dcb}\right) \mathrm{Ru}(\mathrm{CN})_{3}-\mathrm{CN}-\mathrm{Ru}(\mathrm{bpy})_{2}-\mathrm{CN}-\mathrm{Ru}(\mathrm{bpy})_{2}-\right.$ $\mathrm{CN}]^{2-}$ with respect to the $\left[\left(4,4^{\prime}-\mathrm{dcb}\right) \mathrm{Ru}(\mathrm{CN})_{4}\right]^{4-}$ sensitizer. This result is consistent with the higher light harvesting efficiency of the trinuclear species and support the presence of an antenna effect taking place in the $-\mathrm{Ru}(\mathrm{bpy})_{2}-\mathrm{CN}-\mathrm{Ru}(\mathrm{bpy})_{2}-\mathrm{CN}$ unit.

\section{Photoinduced charge separation}

Two simple dyad systems on a semiconductor surface are schematized in figure 6 to show how a sequence of intercomponent electron transfer steps involving the chromo- 


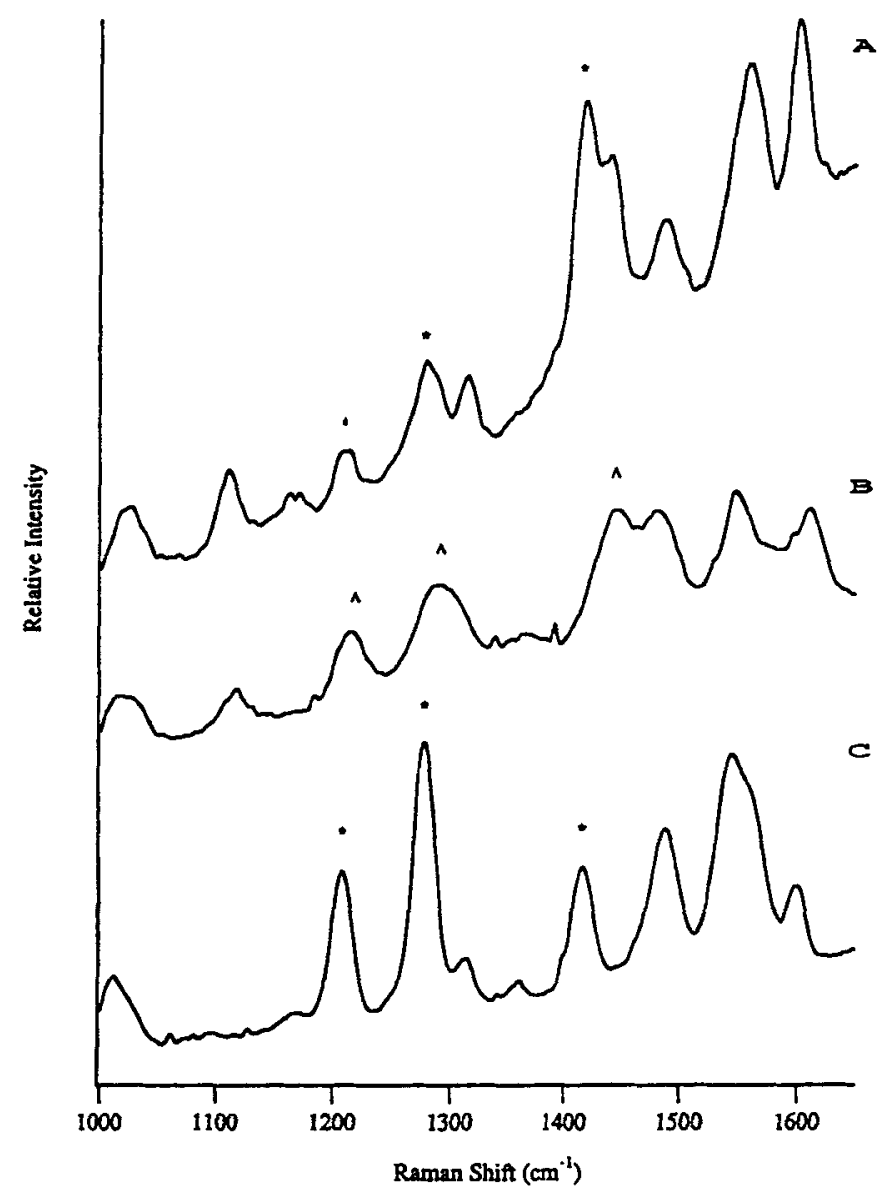

Figure 4. Time resolved resonance Raman spectra of $(\mathrm{A})\left[\left(4,4^{\prime}-\mathrm{dcb}\right) \mathrm{Ru}(\mathrm{CN})_{3}\right.$ $\left.\mathrm{CN}-\mathrm{Ru}(\mathrm{bpy})_{2}{ }^{-} \mathrm{CN}-\mathrm{Ru}(\mathrm{bpy})_{2}-\mathrm{CN}\right]^{2-}$, (B) $\left[\left(4,4^{\prime}-\mathrm{dcb}\right) \mathrm{Ru}(\mathrm{CN})_{4}\right]^{4-}$ and $(\mathrm{C})[(\mathrm{bpy})$ $\left.\mathrm{Ru}(\mathrm{CN})_{4}\right]^{4-}$ in $\mathrm{H}_{2} \mathrm{O}$ at $\mathrm{pH}$ 7. Relevant excited state bands are marked with asterisks and arrows.

phoric molecular component (photosensitizer, P), covalently linked acceptor (A) or donor (D) components, and the semiconductor could be used to produce the hole in the oxidized sensitizer and the injected electron at spatially remote sites. In principle, this should largely reduce the rate of electron-hole recombination, and thus increase the overall cell efficiency.

In principle, an extension from dyads to larger systems (as done with charge separating triads, tetrads, pentads, etc.) can be envisioned in semiconductor sensitization as well. In evaluating the merit of this idea, however, a fundamental thermodynamic limitation should be kept in mind, each additional charge separation step adds a step down in the driving force obtainable from the device. Going to larger systems, therefore, is expected to require a sacrifice either in the energy of the absorbed photons or in the open-circuit voltage obtainable, and thus ultimately in the efficiency of energy conversion. It is evident that a compromise between charge separation and energy losses, to be found likely at the level of a dyad, should be looked for. 


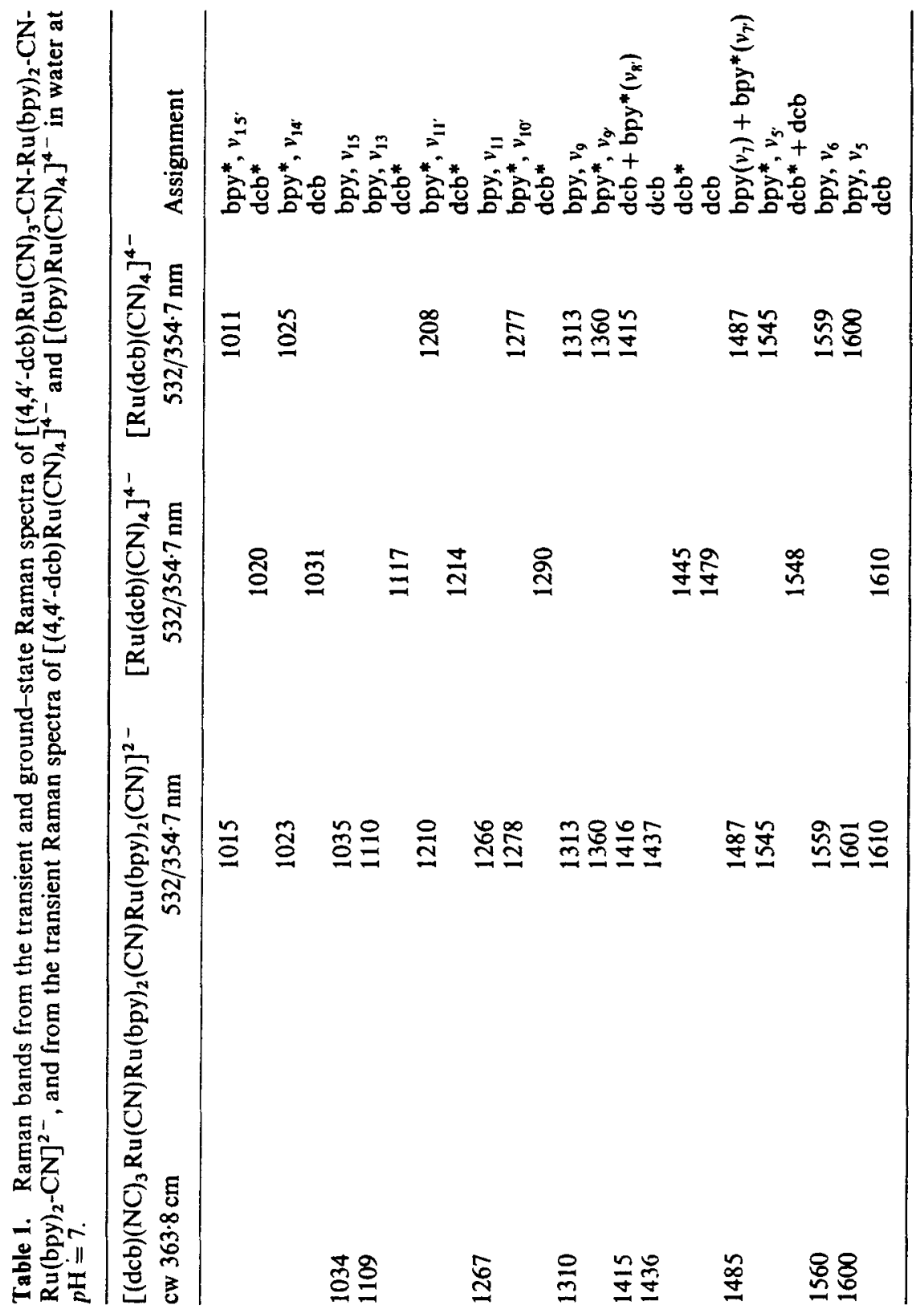




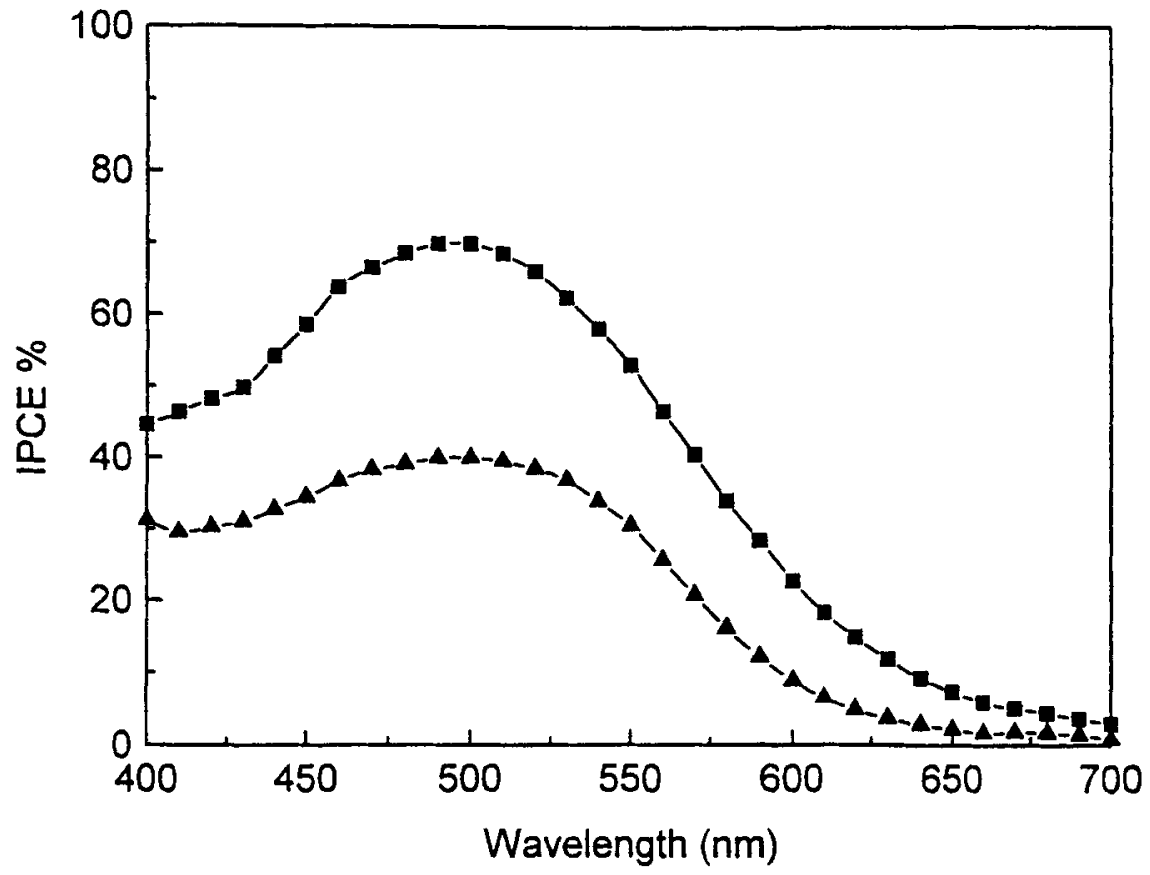

Figure 5. Photoaction spectra of $\left[4,4^{\prime}-\mathrm{dcb}\right) \mathrm{Ru}(\mathrm{CN})_{3}-\mathrm{CN}-\mathrm{Ru}(\mathrm{bpy})_{2}-\mathrm{CN}$ $\left.\mathrm{Ru}(\text { bpy })_{2} \mathrm{CN}\right]^{2-}$, (squares) and $\left[\left(4,4^{\prime}-\mathrm{dcb}\right) \mathrm{Ru}(\mathrm{CN})_{4}\right]^{4-}$ (triangles) measured in a thin layer cell containing a solution of $0.03 \mathrm{M} \mathrm{I}_{2}$ and $0.3 \mathrm{M} \mathrm{LiI}$ in acetonitrile.

a

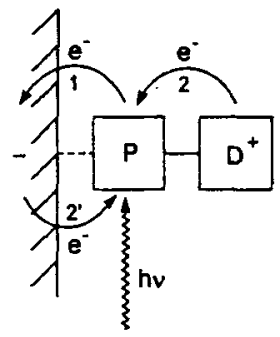

b

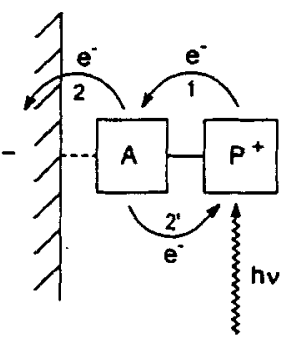

Figure 6. Schematic representation of sequences of electron transfer processes involving dyad systems adsorbed on a semiconductor.

In order for schemes such as those of figure 6 to be implemented, several non-trivial problems must be solved. Aside from various important issues related to molecular architecture, delicate problems of kinetic nature must be addressed. As a matter of fact, 
the kinetics of each of the electron transfer steps must be optimized, so as to bring to $100 \%$ efficient charge separation. In particular, the key to the problem is likely to be the competition between the secondary electron transfer step ( 2 in figure 6 ) and the primary charge recombination process ( 2 in figure 6 ). It is evident that a good deal of control on the factors (driving force, reorganizational barriers, electronic factors) that govern electron transfer rates must be reached before a successful supramolecular device of this kind is developed. Some attempts towards the design, synthesis and photophysical characterization of these types of charge separating photosensitizers will be discussed.

One strategy to increase the charge separation lifetime is to covalently bound an electron transfer donor to the chromophore (figure 6a). With this objective the supramolecular sensitizer $\mathrm{Ru}\left(4,4^{\prime}-\mathrm{dcbH}\right)_{2}$ (bpy-PTZ) where $\mathrm{PTZ}$ is phenothiazine was s!nthesized ${ }^{12}$. The behaviour of this complex on transparent $\mathrm{TiO}_{2}$ indicate that less than $20 \mathrm{~ns}$ after excitation of the Ru chromophore, an electron is injected into the semiconductor and the PTZ group reduces $\mathrm{Ru}(\mathrm{III})$ to $\mathrm{Ru}(\mathrm{II})$, as shown in figure 7. From the photophysical data obtained on $\mathrm{MeOH}$ solutions of the complex, the rate of the intramolecular electron process from PTZ to the Ru(III)-(4,4'dcb $\left.{ }^{-}\right)$MLCT excited state is of the order of $2.5 \times 10^{8} \mathrm{~s}^{-1}$. It is therefore likely that charge injection to the conduction band of the semiconductor favourably competes with intramolecular reductive quenching of the excited chromophore. The interfacial electron transfer reaction produces a charge separated state which is remarkably long lived, decaying with a rate $\mathrm{kel}=3.6 \times 10^{3} \mathrm{~s}^{-1}(1)$.

$$
\mathrm{TiO}_{2}\left(\mathrm{e}^{-}\right)\left|-\mathrm{Ru}^{\mathrm{Il}}-\mathrm{PTZ}+\rightarrow \mathrm{TiO}_{2}\right|-\mathrm{Ru}^{\mathrm{II}}-\mathrm{PTZ} \text {. }
$$

As a result, when the complex is used as a sensitizer in regenerative solar cell, with iodide as an electron donor, the open circuit photovoltage (Voc) is increased to about $100 \mathrm{mV}$ with respect to the Voc observed for the model complex $\operatorname{Ru}\left(4,4^{\prime}-\mathrm{dcb}\right)_{2}(\mathrm{dmb})^{2+}$ $\left(\mathrm{dmb}=4,4^{\prime} \text {-dimethyl-2,2'-bipyridine }\right)^{12}$. The strategy of vectorial transiation of the photogenerated hole away from interface seems to be therefore successful in preventing charge recombination and may increase solar conversion efficiencies.

An attempt to model a charge separating sensitizer of the type sketched in figure $6 \mathrm{~b}$ is represented by the dyad systems shown in figure 8 . Both dyads contain $R u(I I)-$ $\mathrm{Rh}(\mathrm{III})$ metal centers, but with different chromophoric ligands (4,7-dimethyl-1, 10

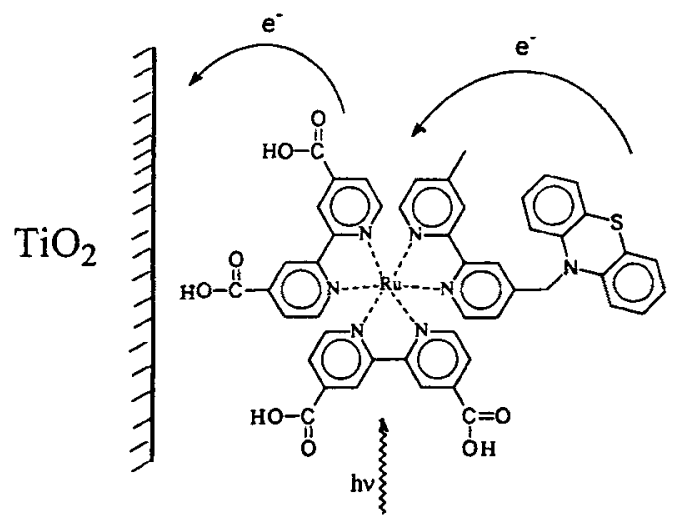

Figure 7. Sequences of intramolecular and interfacial electron transfer processes for the $\mathrm{Ru}(\mathrm{II})$ polypyridine-phenothiazine sensitizer adsorbed on $\mathrm{TiO}_{2}$. 


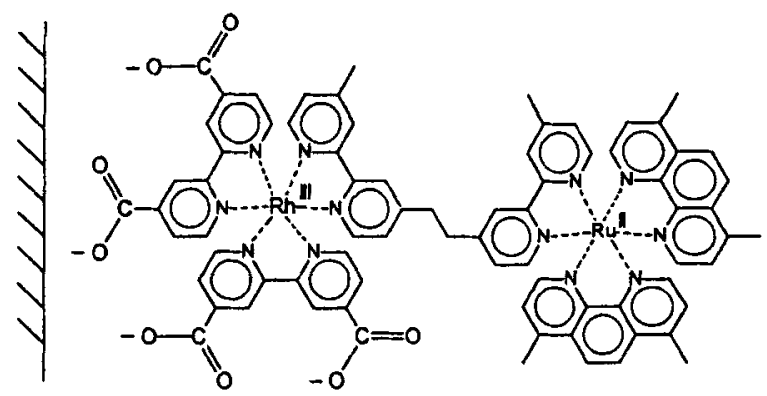

a

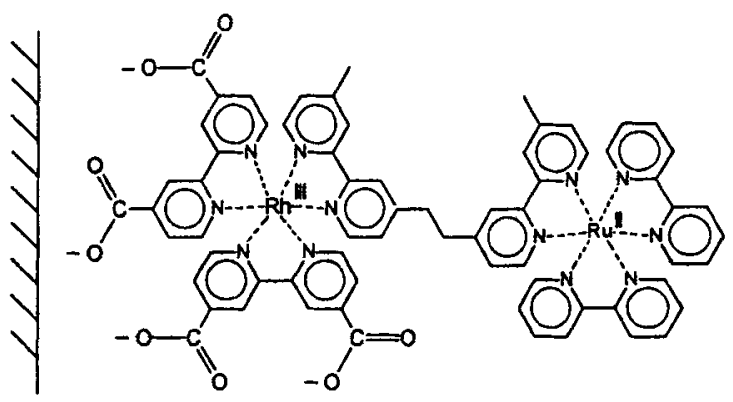

b

Figure 8. Schematic structures of (a) $\left[\left(4,7-\mathrm{Me}_{2} \text { phen }\right)_{2} \mathrm{Ru}\left(\mathrm{Mebpy}-\mathrm{CH}_{2}-\mathrm{CH}_{2}-\right.\right.$ Mebpy)-Rh(4,4'-dcbH$\left.)_{2}\right)^{5+}$ and (b) $\left[(\text { bpy })_{2} \mathrm{Ru}\left(\mathrm{Mebpy}-\mathrm{CH}_{2}-\mathrm{CH}_{2}-\mathrm{Mebpy}\right)-\right.$ $\left.\mathrm{Rh}\left(4,4^{\prime}-\mathrm{dcbH} \mathrm{H}_{2}\right)_{2}\right]^{\mathrm{s}}$ charge separating sensitizers.

phenanthroline, $\mathrm{Me}_{2}$ phen; and 2,2' bipyridine, bpy) at the Ru centers. The presence of carboxy-substituted bipyridine at the $\mathrm{Rh}$ (III) centre allow for binding the dyads to the semiconductor surface. In photoelectrochemical experiments performed in photoregenerative cells, the photocurrent observed for the two dimers are lower than those observed for the model complex $\mathrm{Ru}\left(4,4^{\prime}-\mathrm{dcbH}_{2}\right)_{2}\left(\mathrm{Me}_{2} \mathrm{bpy}\right)^{2+}$, following the order $\mathrm{Ru}$ model $>\mathrm{Ru}\left(\right.$ phen)- $\mathrm{Rh}\left(4,4^{\prime}-\mathrm{dcb}\right)>\mathrm{Ru}(\mathrm{bpy})-\mathrm{Rh}\left(4,4^{\prime}-\mathrm{dcb}\right)$ (figure 9). For a stepwise electron injection into the semiconductor, such as that depicted in scheme $6 \mathrm{~b}$, the overall charge injection yield is given by (2)

$$
\eta_{\mathrm{inj}}=\left(\mathrm{k}_{1} /\left[\mathrm{k}_{1}+1 / \tau\left(\mathrm{P}^{*}\right)\right]\right)\left(\mathrm{k}_{2} /\left[\mathrm{k}_{2}+\mathrm{k}_{2}\right]\right) \text {. }
$$

The fact that intramolecular electron transfer rates for excited state oxidative quenching of the $\mathrm{Ru}^{*}$ chromophore by the adjacent $\mathrm{Rh}(\mathrm{III})$ centre are $\mathrm{kel}=10^{9}$ for $\mathrm{Ru}\left(\mathrm{Me}_{2}\right.$ phen)- $\mathrm{Rh}\left(4,4^{\prime}-\mathrm{dcb}\right)$ and $\mathrm{kel}=2.6 \times 10^{7}$ for $\mathrm{Ru}(\mathrm{bpy})-\mathrm{Rh}\left(4,4^{\prime}-\mathrm{dcb}\right)$, may only account, due to the long excited-state lifetime of the $R u(I I)$ based excited state, for a $10 \%$ difference in the photocurrent observed. The $50 \%$ difference which is obtained for the two dimers can be explained if a difference in the charge recombination rates $\left(\mathrm{k}_{3}\right)$ exists. To obtain proof that charge injection into the semiconductor by the excited $\mathrm{Ru}^{*}$ chromphores is mediated by intramolecular electron transfer to $\mathrm{Rh}$ (III) is not therefore a trivial problem and will require the use of fast time-resolved spectroscopy. 


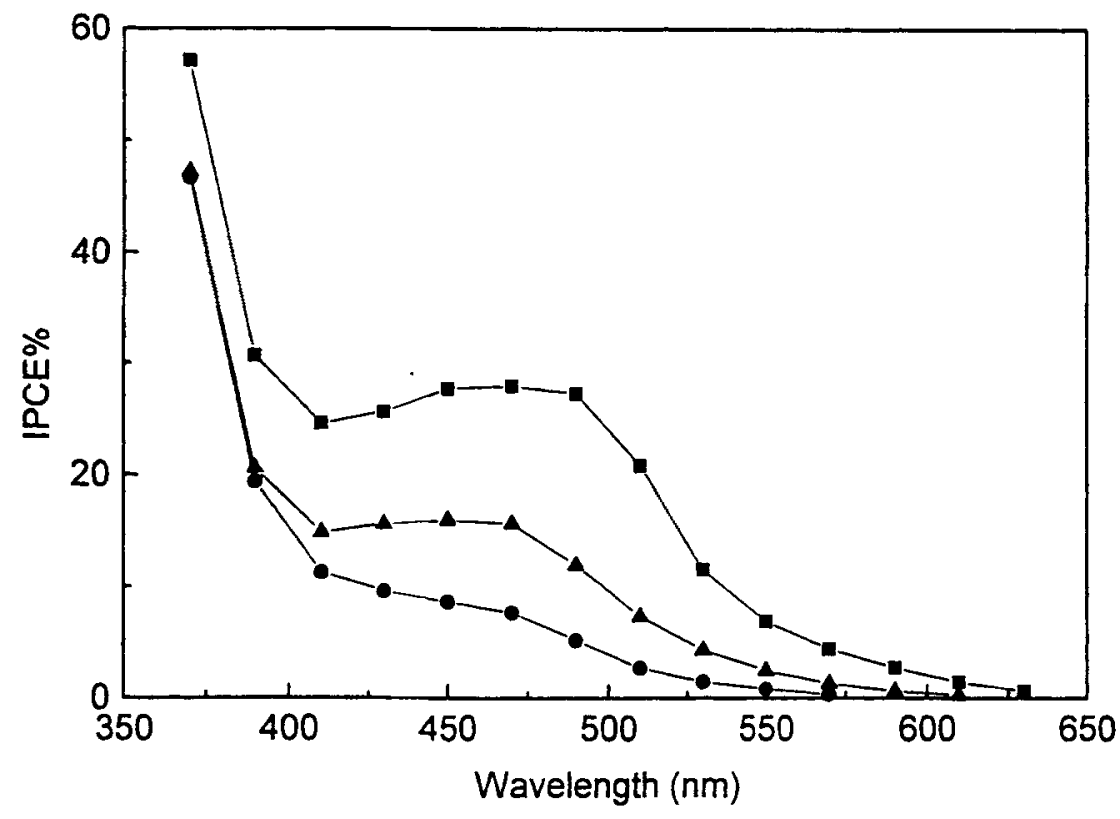

Figure 9. Photoaction spectra of $\left.\mathrm{Ru}\left(4,4^{\prime}-\mathrm{dcbH}\right)_{2}\right)_{2}\left(\mathrm{Me}_{2} \mathrm{bpy}\right)^{2+}$ (squares, $[(4,7-$ $\mathrm{Me}_{2}$ phen) $\left.{ }_{2} \mathrm{Ru}\left(\mathrm{Mebpy}-\mathrm{CH}_{2}-\mathrm{CH}_{2}-\mathrm{Mebpy}\right)-\mathrm{Rh}\left(4,4^{\prime}-\mathrm{dcbH}\right)_{2}\right]^{\mathrm{st}}$ (triangles), and [(bpy) ${ }_{2} \mathrm{Ru}\left(\mathrm{Mebpy}-\mathrm{CH}_{2}-\mathrm{CH}_{2}-\mathrm{Mebpy}-\mathrm{Rh}\left(4,4^{\prime}-\mathrm{dcbH}_{2}\right)_{2}\right]^{5+}$ (circles) measured in a thin layer cell containing a solution of $0.03 \mathrm{M} \mathrm{I}_{2}$ and $0.3 \mathrm{M} \mathrm{LiI}$ in acetonitrile.

\section{Remote electron injection}

The type of linkage between mononuclear or polynuclear complexes and the semiconductor surface is of particular relevance in the design of a molecular sensitizer. A chemical bond between a sensitizer and a semiconductor surface serves not only to anchor the sensitizer in place, but may also enhance electronic coupling. Recently, it has been observed that mononuclear sensitizers containing 2,2'-bipyridine with a pendant acac derivative, convert photons to electrons with monochromatic photon-tocurrent efficiencies of the order of $30 \%{ }^{13}$. Since the surface link and the sensitizers are separated by a $n$-propyl spacer, the high efficiency indicates that intimate electronic contact between the surface link and the chromophoric ligand is not a strict requirement in the design of sensitizers for photovoltaic devices. In an effort to achieve improved molecular control of the sensitizer, orientation the binuclear $\left[\left(4,4^{\prime}\right.\right.$ $\left.\left.\mathrm{dcbH}{ }_{2}\right) \mathrm{Re}^{\mathrm{I}}(\mathrm{CO})_{3}-\mathrm{NC}-\mathrm{Ru}^{\mathrm{Il}}(\mathrm{bpy})_{2}(\mathrm{CN})\right]\left(\mathrm{PF}_{6}\right)$ complex and the linkage isomer $\left[\left(4,4^{\prime}-\right.\right.$ $\left.\left.\mathrm{dcbH}_{2}\right) \operatorname{Re}^{\mathrm{l}}(\mathrm{CO})_{3}-\mathrm{NC}-\mathrm{Ru}^{\mathrm{II}}(\mathrm{bpy})_{2}(\mathrm{CN})\right]\left(\mathrm{PF}_{6}\right)$ were synthesized ${ }^{14}$.

Both compounds display intense $\mathrm{d}_{\pi} \mathrm{Ru}^{\mathrm{il}}-\pi^{*}(\mathrm{bpy}) \mathrm{MLCT}$ bands in the visible region. MLCT transitions localized on the Re moiety are at higher energy and extend to the near UV. In these species, efficient photoinduced energy transfer processes from MLCT states localized on the Re unit to MLCT states localized on the Ru unit take place. Given the similarity in structure with the analogous binuclear complex, [phen) $\left.\operatorname{Re}^{\prime}(\mathrm{CO})_{3}-\mathrm{NC}-\mathrm{Ru}^{\mathrm{II}}(\mathrm{bpy})_{2}(\mathrm{CN})\right]\left(\mathrm{PF}_{6}\right)$, for which time-resolved infrared measurements gave an energy transfer rate constant of $2 \times 10^{11} \mathrm{~s}^{-1}$, the intercomponent transfer processes are also expected to fall in the ps time domain ${ }^{15}$. 
A special feature of these dimers is that the facial geometry of the Re center holds the $\mathrm{Ru}$ sensitizer proximate to the $\mathrm{TiO}_{2}$ surface. The results of photoelectrochemical measurements, performed on $\mathrm{TiO}_{2}$ electrodes, show that despite the absence of a direct link between the chromophoric ligands and the semiconductor surface, remarkably high photocurrent efficiencies in the wavelength range $450-600 \mathrm{~nm}$ are observed for both dimers ${ }^{14}$. At present it is unclear whether charge injection to the semiconductor is directly promoted from the excited Ru center, or if the process is mediated by electron hopping from the $\left(\mathrm{bpy}^{-}\right)$ligand to the surface bound dcbH ligand. It appears however that charge injection can be very efficient even with chromophore that are not directly bound to the semiconductor surface. The clarification of role of the supramolecular structure in promoting or mediating the electron transfer process should provide new, interesting insights into interfacial electron transfer processes in these materials.

\section{Acknowledgements}

This work was supported by MURST, European Community, contract No J0R3CT960107, and by National Renewable Energy Laboratory (NREL XAD-3-12113-04) and National Science Foundation (CHE-9322559) J.M.

\section{References}

1. Meyer T J 1986 Pure Appl. Chem. 581193

2. (a) Balzani V and Scandola F 1991 Supramolecular Photochemistry, Horwood, Chichester, (b) Balzani V and De Cola L 1992 Supramolecular Chemistry, Kluwer, Dordrecht; (c) Sauvage J-P, Collin J-P, Chambron J-C, Guillerez S, Coudret C, Balzani V, BarigellettiF, De Cola L and Flamigni L 1994 Chem. Rev. 94993

3. (a) Scandola F, Indelli M T, Chiorboli C and Bignozzi C A 1990 Top. Curr. Chem. 158 73; (b) Scandola F, Bignozzi C A and Indelli M T 1993 in Photosensitization and Photocatalysis Using Inorganic and Organometallic Compounds, (eds) $\mathrm{K}$ Kalyanasundaram and $\mathrm{M}$ Gratzel, Kluwer, Dordrecht, p. 161-216; (c) Photochemistry of Polypyridine and Phorpyrin Complexes; Academic Press: London, 1992.

4. O'Regan B and Grätzel M 1991 Nature 353737

5. (a) Gherisher H, Michel Beyerle M E, Rebentrost F and Tributsch H 1968 Electrochim. Acta 13 1509; (b) Tributsch H 1969 Ber. Bunsen.-Ges. Phys. Chem. 73 582; (c) Tributsch H. and Calvin M 1971 Photochem. Photobiol. 14 95; (d) Memming R and Tributsch H 1971 J. Phys Chem. 75 562; (e) Tributsch H 1972 Photochem. Photobiol. 16 261; (f) Gherisher H 1972 Photochem. Photobiol. 16 243; (g) Gherisher H and Willig F 1976 Top. Curr. Chem. 61 31; (h) Clark W D K and Sutin N J 1977 J. Am. Chem. Soc. 99 4676; (g) Spitler M T and Calvin M J 1977 J. Chem. Phys. 66 4294; (h) Miyasaka T, Watanabe T, Fujisima A and Honda K, 1978 J. Am. Chem. Soc. 100 6657; (g) Miyasaka T, Watanabe T, Fujisima A and Honda K 1979 Nature. 277 638; (e) Shepard Jr. V R and Armstrong N R 1979 J. Phys Chem. 83 1268; (f) Jaeger C D, Fan F F and Bard A J 1980 J. Am. Chem. Soc. 1022592

6. (a) Amadelli R, Argazzi R, Bignozzi C A and Scandola F 1990 J. Am. Chem. Soc. 112 7099; (b) Nazeeruddin M K, Liska P, Moser J, Vlachopoulos N and Grätzel M 1990 Helv. Chim. Acta 731788

7. (a) Nazeeruddin M K, Kay A, Rodicio I, Humphry-Baker R, Muller E, Liska $P$, Vlachopouios N and Grätzel M $1993 \mathrm{~J}$. Am. Chem. Soc. 115 6382; (b) Argazzi R, Bignozzi C A, Heimer T A, Castellano F N and Meyer G J 1994 Inorg. Chem. 33 5741; (c) Bignozzi C A, Schoonover J R and Scandola F Progr. Inorg. Chem. In press

8. (a) Bignozzi C A, Argazzi R, Chiorboli C, Scandola F, Dyer R B, Schoonover J R and Meyer T J 1994 Inorg. Chem. 33 1652; (b) Bignozzi C A, Argazzi R, Schoonover J R, Meyer G J and Scandola F 1995 Sol. Energy Mater. Sol. Cells 38187

9. Smestad G, Bignozzi C A, Argazzi R 1994 Sol. Energy Mater. Sol. Cells 32259 
10. Timpson C J, Bignozzi C A, Sullivan B P, Kober E D and Meyer T J 1996 J. Phys. Chem. 100 2915

11. Gutman V 1976 Elv. Chim. Acta. 21661

12. Argazzi R, Bignozzi C A, Heimer T A, Castellano F N and Meyer G J 1995 J. Am. Chem. Soc. 11711815

13. Heimer T A, D' Arcangelis S T, Farzad F, Stipkala J M and Meyer G J Inorg. Chem. Submitted.

14. Argazzi R, Bignozzi C A, Heimer T A, Meyer G J Inorg. Chem. Submitted

15. Schoonover J R, Gordon K C, Argazzi R, Woodruff W H, Peterson K A, Bignozzi C A, Dyer R B and Meyer T J 1993 J. Am. Chem. Soc. 11510996 